This work was supported by Action Research for the Crippled Child. We are grateful to Dr P Brankin, Oxford Medical Systems Ltd, for technical help and to Miss S Ruddock, who typed the manuscript.

1 Wasterlain CG. Effects of neonatal status epilepticus on rat brain development. Neurology 1976;26:975-86.

${ }^{2}$ Wasterlain CG. Vulnerability of developing rat brain to electroconvulsive seizures. Arch Neurol 1973;29:38-45.

${ }^{3}$ Ment LR, Freedman RM, Ehrenkranz RA. Neonates with seizures attributable to perinatal complications. Am f Dis Child 1982;136:548-50.

${ }^{4}$ Holden KR, Mellits ED, Freeman JM. Neonatal seizures. I. Correlation of prenatal and perinatal events with outcomes. II. A multivariate analysis of factors associated with outcome. Pediatrics $1982 ; 70: 165-85$.

(Accepted 25 Fanuary 1983)

Neonatal Unit, Department of Paediatrics, University of Oxford, John Radcliffe Maternity Hospital, Oxford OX3 9DU

JANET A EYRE, MB, CHB, research fellow

ROWENA C OOZEER, senior technician

ANDREW R WILKINSON, MB, MRCP, consultant perinatal paediatrician

Correspondence to: $\operatorname{Dr}$ A R Wilkinson.

\section{Cardiac complications of carbamazepine intoxication: treatment by haemoperfusion}

Although carbamazepine is widely prescribed for epilepsy and trigeminal neuralgia, it rarely seems to be taken in overdosage. Manifestations of severe acute poisoning include sinus tachycardia, ataxia, convulsions, coma and respiratory depression. ${ }^{1-4}$ First degree atrioventricular block has also been noted ${ }^{12}$ but has not been well documented. We describe a case of acute carbamazepine intoxication complicated by severe myocardial depression with bradycardia, conduction defects, hypotension, and oliguria. There was no improvement with conservative management, but the patient recovered after charcoal haemoperfusion.

\section{Case report}

A 50 year old man with no history of heart disease was admitted in deep coma 12 hours after apparent ingestion of $20 \mathrm{~g}$ carbamazepine. There was no response to any stimulation, the pupils were fixed and dilated, and there was divergent strabismus. Respiratory rate was $14 / \mathrm{min}$, blood pressure $85 / 60 \mathrm{~mm} \mathrm{Hg}$, and pulse rate $52 / \mathrm{min}$; an electrocardiogram showed first degree atrioventricular block ( $P-R$ interval $0.28 \mathrm{~s}$ ) with normal $Q R S$ and $\mathrm{QT}_{\mathrm{c}}$ intervals. Gastric aspiration and lavage were carried out after endotracheal intubation. There were no haematological or biochemical abnormalities, and the plasma carbamazepine concentration (enzyme multiplied immunoassay technique) was $62 \mathrm{mg} / 1(261 \mu \mathrm{mol} / \mathrm{l})$.

Arterial blood gas analysis showed acute respiratory acidosis, and assisted ventilation was required for six hours. His condition deteriorated further with peripheral circulatory failure, oliguria (urine flow $10 \mathrm{ml} / \mathrm{h}$ ), hypotension (systolic blood pressure $50 \mathrm{~mm} \mathrm{Hg}$ ), and an irregular and slow pulse. Electrocardiography showed loss of $P$ waves, occasional ventricular ectopic beats, and prolongation of the QRS interval (figure). Intravenous atropine $(1.2 \mathrm{mg})$ and glucagon $(15 \mathrm{mg})$ had no effect, and after infusion of a litre of plasma protein solution the central venous pressure remained raised at

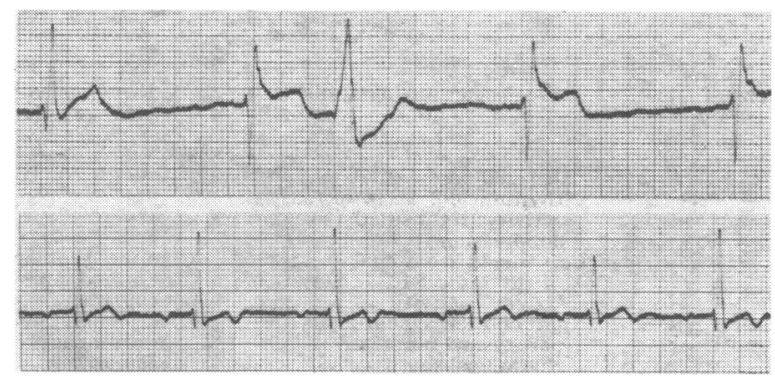

Electrocardiogram monitor traces shortly after admission (top) and after haemoperfusion (bottom).
$14 \mathrm{~cm}$ of water. Dopamine $(5 \mu \mathrm{g} / \mathrm{kg} / \mathrm{min})$ was infused; the heart rate rose to $67 / \mathrm{min}$ and the blood pressure to $110 / 70 \mathrm{~mm} \mathrm{Hg}$, and the urine output increased.

Forty hours after admission he was still deeply unconscious and continuous inotropic support was required to maintain the pulse rate, blood pressure, and urine flow. Electrocardiographic appearances were essentially unchanged. Charcoal haemoperfusion was therefore carried out (Haemacol, flow rate $200 \mathrm{ml} / \mathrm{min}$ ) in an attempt to remove the carbamazepine. Haemoperfusion was stopped after five hours, at which time he was extubated and responded to verbal commands. Dopamine was no longer required, and electrocardiography showed sinus rhythm, first degree atrioventricular block (P-R interval $0.26 \mathrm{~s}$ ) and normal $\mathrm{QRS}$ and $\mathrm{QT} \mathrm{T}_{\mathrm{c}}$ intervals. During haemoperfusion the plasma carbamazepine concentration fell from 31 to $15 \mathrm{mg} / \mathrm{l}$ (131 to $63 \mu \mathrm{mol} / \mathrm{l}$ ) and the initial clearance across the column was $174 \mathrm{ml} / \mathrm{min}$. At two and five hours, however, the clearance had fallen to $80 \mathrm{ml} / \mathrm{min}$ and the estimated total amount of drug removed was less than $1 \mathrm{~g}$.

The following day the electrocardiogram was within normal limits. The patient remained confused and ataxic for a further four days and was subsequently transferred to a psychiatric ward.

\section{Comment}

Such profound and prolonged myocardial depression with bradycardia, conduction defects, hypotension, and oliguria has not been reported previously after carbamazepine overdosage despite similar drug concentrations in some patients. ${ }^{34}$ Depressed atrioventricular conduction with complete heart block has occurred, however, with therapeutic use of carbamazepine,$^{5}$ and there seems to be great individual variation in response to the drug's cardiac effects. As in other reports, ${ }^{14}$ haemoperfusion was moderately effective in removing carbamazepine and the fall in drug concentration in our patient was associated with considerable electrocardiographic and clinical improvement.

${ }^{1}$ Gary NE, Byra WM, Eisinger RP. Carbamazepine poisoning: treatment by haemoperfusion. Nephron $1981 ; 27: 203-3$.

2 Rockoff S, Baselt RC. Severe carbamazepine poisoning. Clin Toxicol $1981 ; 18: 935-9$

${ }^{3}$ Sullivan JB, Rumack BH, Peterson RG. Acute carbamazepine toxicity resulting from overdose. Neurology $1981 ; 31: 621-4$.

4 Chan K, Aguanno JJ, Jansen R, Dietzler DN. Charcoal haemoperfusion for the treatment of carbamazepine poisoning. Clin Chem 1981;27: 1300-2.

${ }^{5}$ Hamilton DV. Carbamazepine and heart block. Lancet 1978;i:1365.

(Accepted 7 fanuary 1983)

Regional Poisoning Treatment Centre, University Department of Therapeutics and Clinical Pharmacology, and Department of Clinical Chemistry, Royal Infirmary, Edinburgh EH3 9YW

$P$ J LESLIE, BSC, MB, senior house officer

R HEYWORTH, BSC, PHD, senior biochemist

L F PRESCOTT, MD, FRCPED, consultant physician and reader in clinical pharmacology

Correspondence to: Dr P J Leslie, Department of Therapeutics and Clinical Pharmacology, Ninewells Hospital, Dundee.

SOPEWORT, OR BRUISEWORT. The roots creep under ground far and near, with many joints therein, of a brown colour on the outside and yellowish within, shooting forth in divers places weak round stalks, full of joints, set with two leaves a-piece at every one of them on a contrary side, which are ribbed somewhat like to plantain, and fashioned like the common field white campion leaves, seldom having any branches from the sides of the stalks, but set with flowers at the top, standing in long husks like the wild campions, made of five leaves a-piece, round at the ends, and dented in the middle, of a rose colour, almost white, sometimes deeper, sometimes paler; of a reasonable scent. It grows wild in many low and wet grounds of this land, by brooks and the sides of running waters. It flowers usually in July, and so continues all August, and part of September, before they be quite spent.

Venus owns it. The country people in divers places do use to bruise the leaves of Sopewort, and lay it to their fingers, hands or legs, when they are cut, to heal them up again. Some make great boast thereof, that it is diuretical to provoke urine, and thereby to expel gravel and the stone in the reins or kidneys, and do also account it singularly good to void hydropical waters: and they no less extol it to perform an absolute cure in the French pox, more than either sarsaparilla, guiacum, or China can do; which, how true it is, I leave others to judge. (Nicholas Culpeper (1616-54) The Complete Herbal, 1850.) 